\title{
IMPLEMENTASI METODE MFCC DAN DTW UNTUK PENGENALAN JENIS SUARA PRIA DAN WANITA
}

\author{
Irham Sidik Permana1, Youllia Indrawaty Nurhasanah ${ }^{1}$, Andriana \\ Zulkarnain ${ }^{2}$ \\ ${ }^{1}$ Teknik Informatika Institut Teknologi Nasional Bandung \\ 2 Teknik Elektro Universitas Langlangbuana Bandung \\ irhamsidikp@gmail.com, youllia@itenas.ac.id, Andriana6970@gmail.com
}

\begin{abstract}
ABSTRAK
MFCC (Mel-Frequency Cepstral Coefficient) dan DTW (Dynamic Time Warping) adalah suatu metode dalam mengolah suara, pada penelitian ini pengolahan suara yang dilakukan bertujuan untuk pengenalan jenis suara pria dan wanita. Penentuan jenis suara pria atau wanita biasanya dilakukan dalam penentuan kelompok paduan suara. MFCC merupakan metode untuk ekstraksi ciri, selain MFCC digunakan metode lain yaitu DTW yang merupakan metode pencocokan suara latih dan suara uji, teknik ini berguna untuk menghitung jarak antara dua data dengan pola-pola yang berbeda dan menghitung nilai dan jarak dari data tersebut. Pada penelitian ini dibangun suatu sistem yang dapat mengenali jenis suara pria dan wanita, Jenis suara pada pria dibagi menjadi Tenor, Bariton dan Bass, sedangkan pada wanita dibagi menjadi Sopran, Mezzosopran dan Alto. Hasil Penelitian yang didapat yaitu untuk tingkat akurasi pada wanita dengan jenis suara alto didapatkan presentase $80 \%$, untuk tingkat akurasi jenis suara mezzosopran didapatkan $90 \%$, untuk tingkat akurasi jenis suara sopran didapatkan $80 \%$. Kemudian pada jenis suara pria, untuk jenis suara bass didapatkan tingkat akurasi sebesar $80 \%$, untuk jenis suara bariton didapatkan tingkat akurasi $70 \%$, dan untuk jenis suara tenor didapatkan tingkat akurasi sebesar $60 \%$.
\end{abstract}

Kata kunci : Pengenalan suara, Jenis suara pria dan wanita, MFCC, DTW.

\begin{abstract}
MFCC (Mel-Frequency cepstral coefficient) and DTW (Dynamic Time Warping) is a method of processing voice, in this case the processing voice is detect men and women voice type. Determining the type of man or woman voice is usually use in deciding a choir voice. MFCC is a method for feature extraction, a technique used in MFCC taken based on the human auditory approach, DTW method is for matching practiced voice and test voice, this technique is useful for calculating the
\end{abstract}


distance between two data with different patterns and calculate the value and range of the data. In this research want built a system that can identify male and female voice type, voice type in men divided into Tenor, Bariton and Bass, while the women divided into soprano, Mezzosopran and Alto. Results obtained to the level of accuracy in women with type alto obtained percentage of $80 \%$, to the level of accuracy the type of mezzosopran voice obtained $90 \%$, to the level of accuracy the type of soprano obtained $80 \%$. For a man voice with type bass voice obtained accuracy rate of $80 \%$, for bariton voice obtained accuracy rate of $70 \%$, and for type of tenor voice obtained accuracy rate of $60 \%$.

Kata kunci : Voice recognition, Type of male and female voice, MFCC, DTW. 


\section{PENDAhUlUan}

\subsection{Latar Belakang}

Pengenalan suara adalah suatu pengembangan teknik untuk mengenali dan menterjemahkan masukan suara yang diucapkan oleh perangkat teknologi[ ${ }^{[1]}$. Pada saat ini, sistem pengenalan ucapan menjadi sesuatu hal yang dapat memudahkan interaksi antara manusia dan perangkat teknologi yang ada.

Suara merupakan bagian dari manusia yang dapat dibedakan. Banyak hal-hal yang berkaitan dengan suara, salah satunya adalah pada bidang musik. Dalam teori musik, manusia memiliki jenis suara yang berbeda-beda yaitu terdapat suara tinggi, sedang, dan rendah baik pria maupun wanita. Jenis suara pada pria dibagi menjadi Tenor, Bariton dan Bass, sedangkan pada wanita dibagi menjadi Sopran, Mezzosopran dan $A / t o^{[3]}$. Tetapi sebagian besar orang yang tidak memiliki ilmu mengenai musik mengalami kesulitan dalam menentukan jenis suara mereka. Dalam menentukan jenis suara biasanya dilakukan dengan cara manual menggunakan bantuan dari seorang ahli atau pelatih vokal dengan bantuan alat musik seperti piano. Penentuan jenis suara pria ataupun wanita biasanya dilakukan dalam penentuan kelompok paduan suara. Namun penentuan dengan cara ini memiliki ketergantungan pada pelatih vokal dan alat musik. Untuk itu dibuatlah sistem yang dapat mengenal jenis-jenis suara untuk mempermudah penentuan jenis suara pada pria dan wanita.

Pada proses pengenalan jenis suara pada pria dan wanita dibutuhkan suatu metode, salah satunya adalah MFCC (Mel Frequency Cepstrum Coefficients),metode ini digunakan untuk melakukan ekstraksi ciri (feature extraction), yaitu untuk mendapatkan suatu parameter dan informasi mengenai ciri dari suara seseorang ${ }^{[6]}$. Sedangkan untuk pencocokan pola suara latih terhadap suara yang akan diuji menggunakan metode DTW (Dinamic Time Warping), Teknik DTW ditunjukan untuk mengatasi perbedaan waktu. Proses perbedaan waktu yang dimaksud adalah waktu pada saat proses perekaman pengujian dengan waktu pada template sinyal referensi yang tersedia, prinsip dasarnya adalah dengan memberikan sebuah rentang 'steps' dan digunakan untuk mempertemukan lintasan yang menunjukkan local match (kemiripan) terbesar yang selanjutnya akan dipilih best-matching template ${ }^{[2]}$.

Pada penelitian ini diterapkan metode MFCC untuk mendapatkan ciri dari suara dan DTW digunakan untuk mencocokan suara uji dan data suara latih yang telah tersimpan sebelumnya. Melalui penelitian ini dibangun sebuah aplikasi yang berfungsi untuk mengetahui jenis suara yang terdapat pada pria dan wanita serta mengetahui tingkat akurasi yang didapat dari metode MFCC dan DTW tersebut. 


\subsection{Rumusan Masalah}

Permasalahan yang dibahas pada penelitian ini, yaitu:

1. Bagaimana membuat sistem yang dapat mendeteksi jenis suara pada pria dan wanita.

2. Bagaimana menerapkan metoda MFCC sebagai metode untuk ekstraksi ciri dan metode DTW sebagai pencocokan suara latih dan suara uji.

\subsection{Tujuan}

Tujuan dilakukannya penelitian ini adalah untuk membuat aplikasi yang dapat mendeteksi jenis suara pada pria dan wanita, dengan menerapkan MFCC sebagai metode ekstraksi ciri dan DTW sebagai pencocokan suara latih dan suara uji untuk dapat menganalisa jenis suara pada pria dan wanita.

\subsection{Batasan Masalah}

Batasan masalah pada penelitian ini adalah sebagai berikut :

1. Jenis suara yang dideteksi adalah Sopran, Mezzosopran dan Alto pada wanita, sedangkan pada pria adalah Tenor,Bariton dan Bass.

2. Durasi dari suara yang direkam sebagai data uji dan data latih yaitu huruf vokal /a/berdurasi 2 detik dengan frekuensi sample $16000 \mathrm{~Hz}$.

3. Data uji diambil dari suara ahli vokal yang dilakukan pengujian terhadap aplikasi yang dibangun.

\section{$1.1 \quad$ Studi Literatur}

\subsection{METODOLOGI PENELITIAN}

Pada tahap ini informasi dan referensi mengenai jenis-jenis suara pada pria dan wanita, konsep Mel-Frequency Cepstral Coefficient (MFFC) dan Dynamic Time Warping (DTW), khususnya mengenai cara mendeteksi jenis suara dengan menggunakan MFCC serta DTW, dikumpulkan dan dijadikan landasan pada penelitian ini.

\subsection{Subjek penelitian}

Subjek penelitian pada penelitian ini adalah enam puluh data suara uji untuk 10 suara dari masing masing jenis suara nya seperti Bass, Bariton, Tenor, Alto, Mezzosopran, Sopran dan digunakan MFCC untuk mendapatkan nilai dari vektor suara tersebut yang berguna untuk mendapatkan suatu parameter dan informasimengenai ciri dari suara uji, lalu digunakan juga DTW untuk mencocokan antara vektor ciri dari suara uji dengan suara latih.

\subsection{Studi Pustaka}

Pada tahap ini dilakukan pencarian mengenai pustaka atau penelitianpenelitian yang telah dilakukan sebelumnya yang berhubungan dengan topik atau masalah yang sedang diteliti yang berguna untuk membantu penulis didalam melakukan penelitian ini. 


\section{Metodologi Pembangunan Sistem}

Adapun metodologi pembangunan sistem pada aplikasi pengenalan jenis suara dengan ekstraksi MFCC dan pencocokan DTW yang dibangun digunakan metodologi prototype seperti dapat dilihat pada Tabel 1.

\section{Tabel 1. Metodologi Pembangunan sistem}

\begin{tabular}{|c|c|c|}
\hline No & Fase & Tahap \\
\hline 1 & Analisis & $\begin{array}{l}\text { a. Melakukan analisis terhadap } \\
\text { kebutuhan sistem } \\
\text { fungsionalitas sistem dan } \\
\text { kerja sistem. }\end{array}$ \\
\hline 2 & Design & $\begin{array}{l}\text { a. Menjelaskan proses perancangan } \\
\text { dengan flowchart. } \\
\text { b. Menentukan design permodelan } \\
\text { layout prototype. }\end{array}$ \\
\hline 3 & $\begin{array}{l}\text { Pengembangan } \\
\text { Prototype }\end{array}$ & $\begin{array}{l}\text { Mengembangkan bentuk } \\
\text { prototype dari model hasil } \\
\text { tahapan design ke dalam bentuk } \\
\text { bahasa pemograman. }\end{array}$ \\
\hline 4 & Pengujian & $\begin{array}{l}\text { Melakukan bentuk pengujian } \\
\text { dengan menggunakan tabel uji. }\end{array}$ \\
\hline 5 & Evaluasi & $\begin{array}{l}\text { Melakukan evaluasi dan } \\
\text { perbaikan pada sistem secara } \\
\text { keseluruhan berdasarkan hasil } \\
\text { pengujian yang telah dilakukan }\end{array}$ \\
\hline
\end{tabular}

\section{ANALISIS DAN PEMBAHASAN}

Aplikasi pengenalan jenis suara yang dibangun memiliki beberapa tahap, proses awal adalah dimasukan data suara latih yang dijadikan sebagai database dengan menggunakan mel-frequency cepstral coefficient (MFCC). MFCC merupakan salah satu teknik ektraksi ciri (feature extraction) pada bidang speech recognition yang dilakukan dengan cara mengubah sinyal suara menjadi beberapa parameter yang dapat dianalisis.

Pada proses pengambilan data uji dilakukan perekaman suara dengan bentuk (.wav) dan dilakukan pencocokan antara suara latih dan suara uji dengan menggunakan DTW (Dynamic Time Warping), teknik ini ditujukan untuk mengakomodasi perbedaan waktu antara proses perekaman saat pengujian 
dengan yang tersedia pada template sinyal referensi. Prinsip dasarnya adalah dengan memberikan sebuah rentang 'steps pada sebuah frame-frame waktu dalam sample dan frame-frame waktu dalam template kemudian digunakan untuk mempertemukan lintasan yang menunjukkan local match terbesar (kemiripan) antara time frame yang lurus, hasil dari pencocokan antara suara latih dan suara uji akan didapatkan jenis suara dari user. Gambaran umum dari sistem dapat dilihat pada Gambar 1.

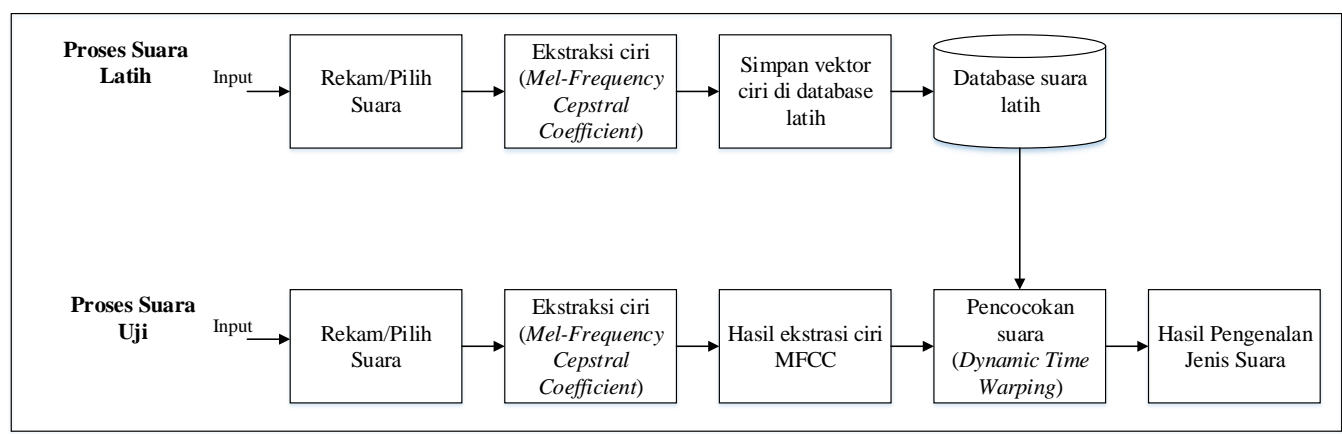

\section{Gambar 1. Gambaran umum sistem}

Berikut merupakan proses utama untuk pengenalan jenis suara pada aplikasi yang dibangun yang terdiri dari proses data suara latih dan proses suara uji.

\subsection{Proses Suara Latih}

Pada proses ini berguna untuk menyimpan sampel data pola jenis suara seperti Tenor, Bariton, Bass untuk pria, dan Sopran, Mezzosopran, Alto untuk wanita. Proses untuk suara latih adalah sebagai berikut:

a. Suara dari user yang dijadikan sebagai suara latih didapatkan dari proses perekaman atau suara tersebut dipilih dari direktori. Suara tersebut memiliki bentuk (.wav) dengan frekuensi sample $16000 \mathrm{~Hz}$, dari suara tersebut didapatkan nilai berupa array suara latih yang akan dilakukan tahap ekstraksi ciri dengan menggunakan MFCC. Contoh sample data array dari suara input user adalah sebagai berikut : $(10,11,13,14,16,18,20,9,6,4)$.

b. Proses ekstraksi ciri dilakukan dengan menggunakan mel-frequency cepstral cefficient (MFCC) untuk mendapatkan beberapa parameter yang dapat di

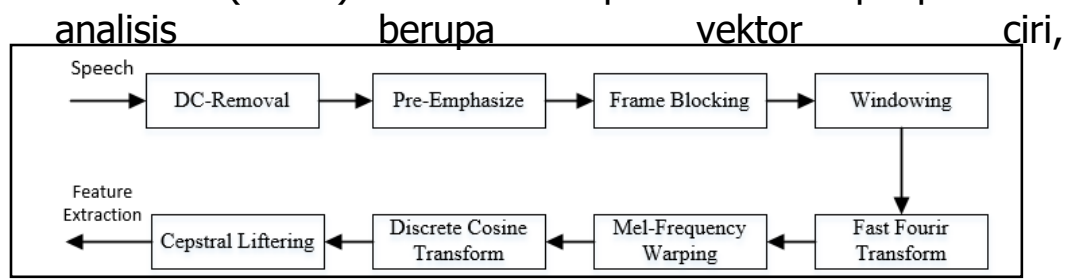

Gambar 2. Proses Mel Frequency Cepstral Coefficient 
Adapun penjelasan dari proses MFCC pada Gambar 2 adalah sebagai berikut:

1. DC Remova/ ditujukan untuk menghitung rata-rata dari data sampel suara dan mengurangi nilai setiap sampel suara dengan nilai rata-rata tersebut, tujuannya adalah membuang data-data yang tidak dibutuhkan di dalam proses suara latih. Proses DC Removal ditampilkan pada Persamaan 1

$\mathrm{y}[\mathrm{n}]=\mathrm{x}[\mathrm{n}]-\bar{x}, 0 \leq \mathrm{n} \leq \mathrm{N}-1$.

Dimana:

y[n]= Sample Signal hasil DC Removal $\quad \bar{x}=$ Nilai rata-rata sample signal asli

$\mathrm{x}[\mathrm{n}]=$ Sample signal asli $\quad \mathrm{N}=$ Panjang signal

Untuk menghitung $D C$ Remova/ pada sampel data sinyal seperti:

$(10,11,13,14,16,18,20,9,6,4)$

Hitung rata-rata sampel sinyal uji : $\bar{x}=\frac{10+11+13+14+16+18+20+9+6+4}{10}=12.1$

Setelah nilai rata-rata diketahui, kurangkan nilai sinyal awal dengan hasil $D C$ Removalsehingga nilai sinyal menjadi :

$$
\mathrm{y}_{0}=10-12,1=-2,1
$$

lakukan cara yang sama untuk nilai sample lain sehingga data sinyal setelah dilakukan DC Removal adalah :

$(-2,1,-1,1,0,9,1,9,3,9,5,9,7,9,-3,1,-6,1,-8,1)$

2. Pre emphasize dilakukan untuk mengurangi noise pada suara masukan, sehingga tingkat akurasi dari proses ekstraksi ciri dapata ditingkatkan. Proses pre emphasize ditampilkan pada Persamaan 2.

$y[n]=s[n]-a . s[n-1], 0.9 \leq a \leq 1.0$

Dimana:

$\mathrm{y}[\mathrm{n}]=$ signa/ hasil pre- emphasize filter

$\mathrm{s}[\mathrm{n}]=$ signal sebelum pre- emphasize filter

$a=$ nilai alpha 
Dalam melakukan penghitungan pre emphasize dengan data hasil dari $D C$ Removal seperti

$(-2,1,-1,1,0,9,1,9,3,9,5,9,7,9,-3,1,-6,1,-8,1)$ dengan $a=0,97$

adalah sebagai berikut:

$$
\begin{aligned}
& Y_{0}=-2.1 \\
& Y_{1}=(-1,1-(-2,1 * 0,97))=0,937 \\
& Y_{2}=(0,9-(-1,1 * 0,97))=1,967
\end{aligned}
$$

Data sinyal baru adalah data sinyal sebelum proses pre emphasis ditambah dengan data hasil pre emphasis di atas. Sehingga sinyal setelah pre emphasis :

$$
\begin{gathered}
N_{n}=N_{n}+Y_{n} \\
N_{0}=-2,1+(-2,1)=-4,2 \\
N_{1}=-1,1+(0,937)=-0,163
\end{gathered}
$$

Sehingga didapatkan nilai sinyal setelah pre emphasis adalah : $10,283)$

$$
(-4,2,-0,163,2,867,2,927,5,957,8,017,10,067,-13,863,-9,193,-
$$

3. Frame blocking adalah suatu proses untuk membagi sampel suara menjadi beberapa frame atau slot. Proses frame blocking ditampilkan Persamaan 3.

Jumlah frame $=T s / M$

Dimana :

$T s=$ Durasi pengambilan suara $(m s)$

$M=$ Panjang frame (ms)

Maka untuk menghitung Ts $=0.2, M=16000$ adalah

frame $=16000 / 0,02=8000$

4. Proses windowing adalah proses untuk mengurangi kesenjangan (discontinuitas) sinyal pada awal dan akhir bingkai setelah proses frame blocking. Seperti pada Persamaan 4.

$$
x(n)=x_{i}(n) w(n)
$$

Dimana:

$X(n)=$ nilai sample signa/ hasil windowing

$x_{i}(n)=$ nilai sample signaldari frame signalke i

$w(n)=$ fungsi window

Untuk menghitung windowing prosesnya adalah sebagai berikut:

$$
W n=0.54-0.46 \cos \frac{2 \times 3.14 \times 0}{8000-1}=0.08
$$


Sehingga,

$$
\begin{aligned}
& X_{0}=-4,1 * 0.08=-0,33 \\
& X_{1}=-0,163 * 0.08=0,01
\end{aligned}
$$

Dengan cara yang sama lakukan pada titik yang lain, dan diperoleh nilai sebagai berikut:

$(-0,33,0,01,0,23,0,23,0,48,0,64,0,80,-1,11,-0,73,-0,82)$

5. Fast Fourier Transform (FFT) berfungsi untuk mengubah domain waktu menjadi domain frekuensi.

Proses FFT ditampilkan pada persamaan 5.

$$
f(n)=\sum_{K=0}^{N-1} y_{k} e^{-2 \pi j k n / N}, n=0,1,2, \ldots, N-1
$$

\section{Dimana :}

$f(n)=$ Frekuensi

$\mathrm{N}=$ Jumlah sample pada masing-masing frame imajiner $(\sqrt{ }-1)$

$$
\begin{aligned}
& k=0,1,2, \ldots,(\mathrm{N}-1) \\
& j=\text { Bilangan }
\end{aligned}
$$

Untuk menghitung FFT pada data sinyal hasil windowing seperti $(-0,33,0,01$ $, 0,23,0,23,0,48,0,64,0,80,-1,11,-0,73,-0,82)$ adalah sebagai berikut :

$$
\begin{aligned}
& \mathrm{F} 0=\left[-0.33\left(\cos \left(\frac{2 p h i * 0 * 0}{10}\right)\right)\right]-j \sin \left(\cos \frac{2 p h i * 0 * 0}{10}\right)+ \\
& {\left[-0.01\left(\cos \left(\frac{2 p h i * 0 * 1}{10}\right)\right)\right] j \sin \left(\cos \frac{2 p h i * 0 * 1}{10}\right)+\cdots . .+\left[-0.82\left(\cos \left(\frac{2 p h i * 0 * 9}{10}\right)\right)\right]-} \\
& j \sin \left(\cos \frac{2 p h i * 0 * 9}{10}\right)=-0.16+0 j=-0.16
\end{aligned}
$$

Dengan cara yang sama lakukan kepada data sinyal lainnya. Sehingga diperoleh data sinyal hasil FFT adalah :

$(-0.16,-0.32,-0.48,-0.64,-0.8,-0.96,-1.12,-1.28,-1.44,1.6)$

6. Mel Frequency Warping dilakukan menggunakan filterbank seperti yang ditunjukan pada Persamaan 6.

Mel $f=\frac{2595 * \log 10\left(1+\frac{f}{700}\right)}{\frac{S i}{2}}$

Dimana :

$$
\begin{aligned}
& \mathrm{Si}=\text { Sinyal awal hasil FFT } \\
& f=f_{0}-f_{n}
\end{aligned}
$$

Untuk data sinyal seperti $(-0.16,-0.32,-0.48,-0.64,-0.8,-0.96,-1.12,-$ $1.28,-1.44,1.6)$ perhitungan mel frequency warping nya adalah sebagai berikut: 


$$
\begin{aligned}
& \mathrm{H}_{0}=\left(\frac{2595 * \log (1+1000 / 700)}{-0.16 / 2}\right)=-3124.95 \\
& \quad \text { Maka penghitungan filterbank untuk } \mathrm{Y}_{0} \text { sebagai berikut : } \\
& \mathrm{Y}_{0}=-0.16^{*}-3124.95=499.99
\end{aligned}
$$

7. DCT adalah proses untuk menghitung mel spectrum sehingga menghasilkan representasi yang baik dari spektral suara. Proses DCT ditampilkan pada Persamaan 7

$c_{n}=\sum_{k=1}^{K}\left(\log S_{k}\right) \cos \left[n\left(k-\frac{1}{2}\right) \frac{\pi}{K}\right] ; \quad n=1,2, \ldots, k$

Dimana:

$S_{k}=$ Keluaran dari proses filterbank pada index $\mathrm{k}$

$K=$ Jumlah koefisien

Untuk perhitungan DCT pada nilai hasil filterbank $=499.99$, Koef $(k)=10$, untuk $\mathrm{n}=0$ maka,

$$
\mathrm{CO}=\log (499.99) \cos [0(0-1 / 2) 3.14 / 10]+\log (499.99)
$$

$\cos [0(1-1 / 2) 3.14 / 10]+\ldots \ldots$

$$
+\log (499.99) \cos [0(9-1 / 2) 3.14 / 10]=26.987
$$

Jadi nilai DCT untuk $\mathrm{C} 0=26.987$, lakukan cara yang sama untuk data sinyal yang lain.

8. Proses cepstral liftering merupakan langkah terakhir dari proses utama MFCC berfungsi untuk meningkatkan kualitas pengenalan suara. Proses cepstral liftering ditampilkan pada Persamaan 8.

$$
W[n]=\left\{\begin{array}{c}
1+\frac{L}{2} \sin \left(\frac{n \pi}{L}\right) \quad n=1,2, \ldots, L \\
0
\end{array}\right.
$$

Dimana:

$$
\begin{aligned}
& \mathrm{L}=\text { Jumlah cepstral coefficients } \\
& \mathrm{N}=\text { Index dari cepstral coefficients }
\end{aligned}
$$

Hasil perhitungan untuk nilai DCT $=26.987$ maka, untuk cepstral liftering pada W0 adalah sebagai berikut:

$$
\begin{aligned}
\mathrm{W} 0 & =26.987 * 10 / 2 * \sin (3.14 / 10) \\
& =0.7392
\end{aligned}
$$

Jadi hasil cepstral liftering pada $\mathrm{W} 0=0.7392$, lakukan cara yang sama untuk data sinyal yang lain dan dari perhitungan cepstral liftering didapatkan suatu vektor ciri yang berguna untuk pencocokan antara suara latih dan suara uji seperti ditunjukan pada Gambar 3. 


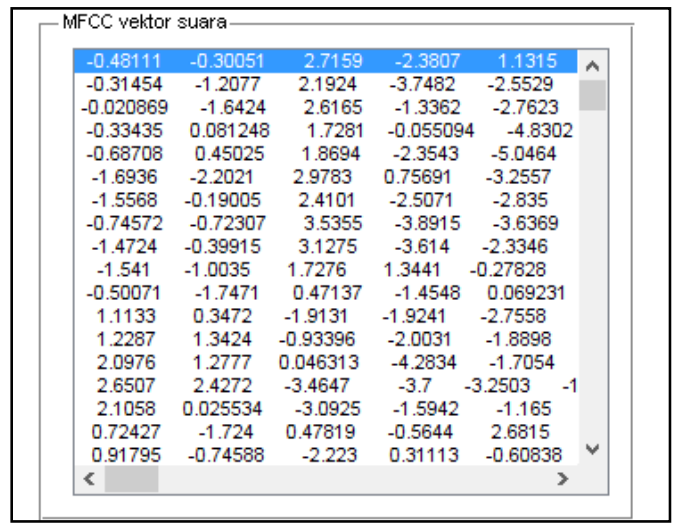

Gambar 3. Hasil ekstraksi suara latih

c. Hasil dari proses ekstraksi didapatkan suatu vektor ciri yang disimpan pada database yang telah ditentukan.

d. Database suara latih akan digunakan sebagai bahan referensi untuk pencocokan data uji dan data latih dalam proses pengenalan jenis suara pada pria dan wanita.

\subsection{Proses suara uji}

Pada proses ini dilakukan pengenalan terhadap suara input dari user. Proses untuk suara uji adalah sebagai berikut:

a. Suara dari user yang dijadikan sebagai suara uji didapatkan dari proses perekaman atau suara tersebut dipilih dari direktori. Suara tersebut memiliki bentuk (.wav) dengan frekuensi sample $16000 \mathrm{~Hz}$.

b. Pada tahap ekstraksi ciri data uji digunakan mel-frequency cepstral cefficient (MFCC) sama seperti pada proses ekstraksi suara latih pada Gambar 2.

c. Proses MFCC pada suara uji berfungsi untuk mendapatkan beberapa parameter yang dapat di analisis berupa vektor ciri yang akan dicocokan dengan hasil ekstraksi ciri dari suara latih.

d. Vektor ciri dari suara input user dicocokan dengan database yang sebelumnya telah tersimpan pada database suara latih. Pencocokan digunakan dengan menggunakan DTW yaitu vektor uji dicocokan dengan vektor suara latih dan didapatkan nilai minimum yang menunjukan jenis suara dari masukan user terhadap aplikasi yang dibangun seperti dapat dilihat pada Gambar 4.

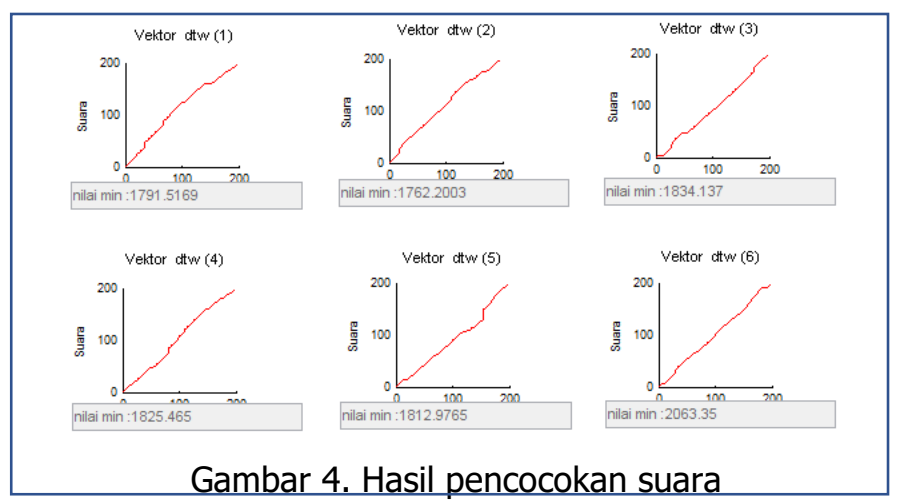


Pada Gambar 4 ditampilkan sampel enam grafik dari suara yang cocok dengan pengenalan jenis suara dari user, grafik tersebut merupakan pencocokan hasil DTW antara vektor suara latih dan vektor suara uji, serta ditampilkan juga nilai minimum yang cocok dengan suara tersebut. Proses DTW ditampilkan pada Persamaan 9.

$$
\begin{aligned}
& D(U, V)=\gamma(m, n) \\
& \gamma(m, n)=d_{\text {base }}\left(u_{i}, v_{j}\right)+\min \left\{\begin{array}{l}
\gamma(i-1, j) \\
\gamma(i-1, j-1) \\
\gamma(i, j-1)
\end{array} .\right.
\end{aligned}
$$

Adapun contoh perhitungan jarak DTW untuk mendapatkan nilai minimum dari data latih dan data uji dapat dilihat seperti pada Tabel 2 . Pada tabel 3 ditunjukan jarak terjumlahkan (cumulative distance) antara 2 vektor yaitu $U=\{2,5,2,5,3\}$, $\mathrm{V}=\{0,3,6,0,6,1\}$ dimana $\mathrm{U}$ merupakan Feature data dan $\mathrm{V}$ merupakan Reference data.

Tabel 2. Contoh Perhitungan nilai DTW

\begin{tabular}{|c|c|c|c|l|}
\hline & $=$ Kolom1 & Kumulatif & $=$ Kumulatif & \\
\hline$(0-2)^{2}$ & 4 & $0+4$ & $\mathbf{4}$ & $\rightarrow$ Minimum \\
\hline$(0-5)^{2}$ & 25 & $4+25$ & 29 & \\
\hline$(0-2)^{2}$ & 4 & $29+4$ & 33 & \\
\hline$(0-5)^{2}$ & 25 & $33+25$ & 58 & \\
\hline$(0-3)^{2}$ & 9 & $58+9$ & 67 & \\
\hline
\end{tabular}

Tabel 3. Cummulative distance 2 vektor

\begin{tabular}{|c|c|c|c|c|c|c|}
\hline \multicolumn{7}{|c|}{ v } \\
\hline & 0 & 3 & 6 & 0 & 6 & 1 \\
\hline 2 & 4 & 5 & 21 & 25 & 41 & 42 \\
\hline u 5 & 29 & 8 & 6 & 31 & 26 & 42 \\
\hline 2 & 33 & 9 & 22 & 10 & 26 & 27 \\
\hline 5 & 58 & 13 & 10 & 35 & 11 & 27 \\
\hline 3 & 67 & 13 & 19 & 19 & 20 & 15 \\
\hline
\end{tabular}

e. Dari pencocokan antara suara latih dan suara uji didapatkan hasil jenis suara dari user tersebut yaitu Tenor, Bariton, Bass, Sopran, Mezzosopran, Alto.

\subsection{Pengujian Sistem}

Pengujian pada aplikasi yang dibangun dilakukan sebanyak 60 suara uji untuk 10 kali pada masing-masing dari jenis suara yaitu alto, mezzosopran, sopran, bass, bariton, dan tenor. Untuk menghitung tingkat validasi pada penelitian ini dihitung dalam (\%) seperti pada Persamaan berikut :

$$
\frac{\text { Hasil Yang Sesuai/Benar }}{\text { Total Seluruh Uji Coba }} \times 100 \%
$$

Tabel 4. Hasil pengujian suara alto

Tabel 5. Hasil pengujian mezzosopran 


\begin{tabular}{|c|c|c|c|c|}
\hline No & file & terdeteksi & Frekuensi & Nilai dtw \\
\hline 1 & Alto1.wav & Alto & $262.950 \mathrm{~Hz}$ & 1194.388 \\
\hline 2 & Alto2.wav & Alto & $262.295 \mathrm{~Hz}$ & 1194.388 \\
\hline 3 & Alto3.wav & Mezzo & $262.295 \mathrm{~Hz}$ & 1941.443 \\
\hline 4 & Alto4.wav & Alto & $262.295 \mathrm{~Hz}$ & 836.014 \\
\hline 5 & Alto5.wav & Alto & $258.006 \mathrm{~Hz}$ & 671.163 \\
\hline 6 & Alto6.wav & Alto & $258.065 \mathrm{~Hz}$ & 1310.85 \\
\hline 7 & Alto7.wav & Sopran & $340.426 \mathrm{~Hz}$ & 1761.625 \\
\hline 8 & Alto8.wav & Alto & $258.065 \mathrm{~Hz}$ & 554.311 \\
\hline 9 & Alto9.wav & Alto & $262.295 \mathrm{~Hz}$ & 648.959 \\
\hline 10 & Alto10.wav & Alto & $258.065 \mathrm{~Hz}$ & 323.394 \\
\hline
\end{tabular}

\begin{tabular}{|c|c|c|c|c|}
\hline No & File & Terdeteksi & Frekuensi & Nilai dtw \\
\hline 1 & Mezzo1.wav & Mezzosopran & $470.588 \mathrm{~Hz}$ & 1933.694 \\
\hline 2 & Mezzo2.wav & Sopran & $363.636 \mathrm{~Hz}$ & 1941.320 \\
\hline 3 & Mezzo3.wav & Mezzosopran & $380.952 \mathrm{~Hz}$ & 1982.229 \\
\hline 4 & Mezzo4.wav & Mezzosopran & $380.952 \mathrm{~Hz}$ & 2024.509 \\
\hline 5 & Mezzo5.wav & Mezzosopran & $380.952 \mathrm{~Hz}$ & 1992.506 \\
\hline 6 & Mezzo6.wav & Mezzosopran & $363.636 \mathrm{~Hz}$ & 2107.368 \\
\hline 7 & Mezzo7.wav & Mezzosopran & $363.636 \mathrm{~Hz}$ & 2083.172 \\
\hline 8 & Mezzo8.wav & Mezzosopran & $470.588 \mathrm{~Hz}$ & 2104.743 \\
\hline 9 & Mezzo9.wav & Mezzosopran & $363.636 \mathrm{~Hz}$ & 2086.619 \\
\hline 10 & Mezzo|10.wav & Mezzosopran & $258.065 \mathrm{~Hz}$ & 1964.273 \\
\hline
\end{tabular}

Berdasarkan Tabel 4 maka hasil dari pengujian untuk jenis suara alto didapatkan tingkat akurasi sebesar:

$$
\frac{8}{10} \times 100 \%=80 \% .
$$

Sedangkan hasil dari pengujian untuk jenis suara mezzosopran berdasarkan Tabel 5 didapatkan tingkat akurasi sebesar:

$$
\frac{9}{10} \times 100 \%=90 \% \text {. }
$$

Tabel 6. Hasil pengujian suara sopran

\begin{tabular}{|c|c|c|c|c|}
\hline No & File & Terdeteksi & Frekuensi & Nilai dtw \\
\hline 1 & Sopran1.wav & Sopran & $727.273 \mathrm{~Hz}$ & 1966.858 \\
\hline 2 & Sopran2.wav & Alto & $277.273 \mathrm{~Hz}$ & 2544.622 \\
\hline 3 & Sopran3.wav & Sopran & $695.652 \mathrm{~Hz}$ & 2229.570 \\
\hline 4 & Sopran4.wav & Sopran & $695.652 \mathrm{~Hz}$ & 2229.570 \\
\hline 5 & Sopran5.wav & Sopran & $761.905 \mathrm{~Hz}$ & 1150.348 \\
\hline 6 & Sopran6.wav & Sopran & $421.053 \mathrm{~Hz}$ & 2476.880 \\
\hline 7 & Sopran7.wav & Sopran & $941.176 \mathrm{~Hz}$ & 2509.588 \\
\hline 8 & Sopran8.wav & Mezzosopran & $457.143 \mathrm{~Hz}$ & 2093.873 \\
\hline 9 & Sopran9.wav & Sopran & $941.176 \mathrm{~Hz}$ & 1839.055 \\
\hline 10 & Sopran10.wav & Sopran & $941.176 \mathrm{~Hz}$ & 1900.455 \\
\hline
\end{tabular}

Untuk hasil pengujian jenis suara sopran dapat dilihat pada Tabel 6 dan mendapatkan tingkat akurasi sebesar:

$$
\frac{8}{10} \times 100 \%=80 \% \text {. }
$$

Tabel 7. Hasil pengujian Bass

\begin{tabular}{|c|c|c|c|c|}
\hline No & file & terdeteksi & Frekuensi & Nilai dtw| \\
\hline 1 & Bass1.wav & Bass & $118.519 \mathrm{~Hz}$ & 1162.44 \\
\hline 2 & Bass2.wav & Bass & $118.519 \mathrm{~Hz}$ & 1568.501 \\
\hline 3 & Bass3.wav & Bariton & $363.636 \mathrm{~Hz}$ & 2217.977 \\
\hline 4 & Bass4.wav & Bass & $106.667 \mathrm{~Hz}$ & 1672.687 \\
\hline 5 & Bass5.wav & Bass & $118.519 \mathrm{~Hz}$ & 1091.104 \\
\hline 6 & Bass6.wav & Bass & $106.667 \mathrm{~Hz}$ & 1602.687 \\
\hline 7 & Bass7.wav & Bass & $118.519 \mathrm{~Hz}$ & 945.219 \\
\hline 8 & Bass8.wav & Bass & $118.519 \mathrm{~Hz}$ & 701.503 \\
\hline 9 & Bass9.wav & Bariton & $363.636 \mathrm{~Hz}$ & 2391.065 \\
\hline 10 & Bass10.wav & Bass & $106.667 \mathrm{~Hz}$ & 1619.498 \\
\hline
\end{tabular}

Berdasarkan tabel 7 maka hasil dari pengujian untuk jenis suara bass didapatkan tingkat akurasi sebesar:

$$
\frac{8}{10} \times 100 \%=80
$$


Tabel 8. Hasil pengujian Bariton

\begin{tabular}{|c|c|c|c|c|}
\hline No & File & Terdeteksi & Frekuensi & Nilai dtw \\
\hline 1 & Bariton1.wav & Bariton & $258.065 \mathrm{~Hz}$ & 1762.203 \\
\hline 2 & Bariton2.wav & Bariton & $262.295 \mathrm{~Hz}$ & 1726.291 \\
\hline 3 & Bariton3.wav & Bariton & $262.295 \mathrm{~Hz}$ & 1500.941 \\
\hline 4 & Bariton4.wav & Tenor & $258.065 \mathrm{~Hz}$ & 1537.663 \\
\hline 5 & Bariton5.wav & Bariton & $285.714 \mathrm{~Hz}$ & 1640.683 \\
\hline 6 & Bariton6.wav & Bass & $313.725 \mathrm{~Hz}$ & 1544.221 \\
\hline 7 & Bariton7.wav & Bariton & $262.295 \mathrm{~Hz}$ & 1628.74 \\
\hline 8 & Bariton8.wav & Bariton & $262.295 \mathrm{~Hz}$ & 1639.076 \\
\hline 9 & Bariton9.wav & Bass & $258.065 \mathrm{~Hz}$ & 1538.501 \\
\hline 10 & Bariton10.wav & Bariton & $262.295 \mathrm{~Hz}$ & 1556.305 \\
\hline
\end{tabular}

Tabel 9. Hasil pengujian Tenor

\begin{tabular}{|c|c|c|c|c|}
\hline No & file & Terdeteksi & Frekuensi & Nilai dtw \\
\hline 1 & Tenor1.wav & Tenor & $380.952 \mathrm{~Hz}$ & 1572.002 \\
\hline 2 & Tenor2.wav & Bass & $380.952 \mathrm{~Hz}$ & 1997.839 \\
\hline 3 & Tenor3.wav & Tenor & $380.952 \mathrm{~Hz}$ & 960.275 \\
\hline 4 & Tenor4.wav & Tenor & $380.952 \mathrm{~Hz}$ & 1532.566 \\
\hline 5 & Tenor5.wav & Tenor & $390.244 \mathrm{~Hz}$ & 1590.883 \\
\hline 6 & Tenor6.wav & Bass & $347.826 \mathrm{~Hz}$ & 1784.478 \\
\hline 7 & Tenor7.wav & Tenor & $390.224 \mathrm{~Hz}$ & 1590.883 \\
\hline 8 & Tenor8.wav & Bass & $367.692 \mathrm{~Hz}$ & 1828.7529 \\
\hline 9 & Tenor9.wav & Bass & $231.884 \mathrm{~Hz}$ & 1495.434 \\
\hline 10 & Tenor10.wav & Tenor & $380.952 \mathrm{~Hz}$ & 1657.625 \\
\hline
\end{tabular}

Untuk hasil pengujian jenis suara bariton dapat dilihat pada tabel 8 dan mendapatkan tingkat akurasi sebesar:

$$
\frac{7}{10} \times 100 \%=70 \% \text {. }
$$

Untuk hasil pengujian jenis suara tenor dapat dilihat pada tabel 9 dan mendapatkan tingkat validasi sebesar:

$$
\frac{6}{10} \times 100 \%=60 \%
$$

\section{KESIMPULAN}

Berdasarkan penelitian mengenai aplikasi untuk pengenalan jenis suara pada pria dan wanita dengan menerapkan metode mel-frequency cepstral coefficient (MFCC) dan Dynamic time warping (DTW) yang dilakukan, diperoleh kesimpulan sebagai berikut :

Aplikasi yang dibangun dapat mengenali jenis suara dengan tingkat akurasi yang berbeda-beda, yaitu untuk tingkat akurasi pada wanita dengan jenis suara alto berdasarkan Tabel 2 didapatkan presentase 80\%, untuk tingkat akurasi jenis suara mezzosopran berdasarkan Tabel 3 didapatkan tingkat akurasi sebesar $90 \%$, untuk tingkat akurasi jenis suara sopran berdasarkan Tabel 4 didapatkan tingkat akurasi sebesar $80 \%$. Kemudian pada jenis suara pria, untuk jenis suara bass berdasarkan Tabel 5 didapatkan tingkat akurasi sebesar $80 \%$, untuk jenis suara bariton berdasarkan Tabel 6 didapatkan tingkat akurasi 70\%, dan untuk jenis suara tenor berdasarkan Tabel 7 didapatkan tingkat akurasi sebesar $60 \%$. 


\section{DAFTAR RUJUKAN}

[1] Angga, S. (2011), Pengenalan Ucapan dengan Ekstraksi Mel-Frequency Cepstrum Coefficients (MFCC). Semarang : Universitas Diponogoro.

[2] Darma Putra. (2011), Verifikasi Biometrika Suara Menggunakan Metode MFCC dan DTW. Bali : Universitas Udayana.

[3] M. N. Al-Azhar, Audio Forensic: Theory And Analysis. Pusat Laboratorium Forensik Polri Bidang Fisika Dan Komputer Forensik, 2011.

[4] Manunggal, HS. 2005. Perancangan dan Pembuatan Perangkat Lunak Pengenalan Suara Pembicara dengan Menggunakan Analisa MFCC Feature Extraction. Surabaya.

[5] Pressman, R.S. 2010, Software Engineering : a practitioner's approach. McGraw-Hill, New York.

[6] Rabiner, Lawrence, and Biing-Hwang Juang,1993, "Fundamentals of Speech Recognition". Prentice Hall, New Jersey.

[7] Waluyanti, Sri, dkk. 2008. Buku Direktorat PSMK Untuk Tehnik Audio Video. 